Goldschmidt 2021 Abstract

https://doi.org/10.7185/gold2021.4711

\section{Unique amphibole-rich mantle beneath the Leningrad kimberlite pipe, West Ukukit field, NE Yakutia}

\section{IGOR ASHCHEPKOV ${ }^{1}$, SVETLANA BABUSHKINA ${ }^{2}$, OLEG OLEINIKOV $^{2}$ AND NIKOLAI MEDVEDEV ${ }^{3}$}

${ }^{1}$ Ihstitute of Geology and Mineralogy SB RAS

${ }^{2}$ Institute of Geology of Diamond and Precious Metals, Siberian Branch,Russian Academy of Sciences, Yakutsk, Russia

${ }_{3}^{3}$ Nikolaev Institute of Inorganic Chemistry 3, Acad. Lavrentiev Ave.3, Novosibirsk, 630090

Presenting Author: igora57@mail.ru

In subcratonic mantle beneath Leningrad pipe, West Ukukit field, Yakutia garnet thermobarometry (Ashchepkov, 2017a) give division to 7 horizons (paleosubduction slabs). Cr-bearing amphiboles are changing from $\mathrm{Cr}$ - hornblendes to pargasites, edinites, K-richterites with increasing pressure determined with new version of amphibole thermobarometer (Ashchepkov, 2017b). They are divided in to 9 groups according to major trace elements and amphibole thermobarometry tracing all branches of the garnet geotherm from 0.8 to to $7.5 \mathrm{GPa}$ The $\mathrm{Cr}$ pargasitic hornblendes of $\mathrm{Fe}$ or- types are covering the 2.5-0.8 $\mathrm{GPa}$ interval. The $\mathrm{Cr}$ pargasites refer to $40 \mathrm{mw} / \mathrm{m} 2$ geotherm in middle SCLM from 2.5 to $4 \mathrm{GPa}$. The edinites are found from 4 to $6 \mathrm{GPa}$ also give LT and HT branches. The richterites of 3 types tracing different PT branches from convective to LT are found in 6 to 7.5 GPa interval. The eclogites compile dense branch in the middle part of mantle column with the highly inclined P-Fe\# trend.

Pargasitic hornblendes with inclined concave REE patterns and $\mathrm{Eu}, \mathrm{HFSE}$ troughs show $\mathrm{Ba}, \mathrm{U}$, Th peaks. The high- T varieties (Gr2a) have less inclined LREE, La (10/C1). Pargasites $3 a$ and $3 b$ have straight line REE and bell like - La to Sm patterns. The Gr3b with Eu minima show $\mathrm{La}_{\mathrm{n}} \sim 140-/ \mathrm{C} 1$. Zr-Hf troughs The Gr3b have HFSE maxima high Ba low U. The Gr3c minima in HFSE , high Rb , low, Th U. Edinites Gr4 - Gr5, Gr 6 show slightly inclined REE pattern $(\mathrm{Gd} / \mathrm{Yb})_{\mathrm{n}} \sim 70-50$. The samples from $\mathrm{Gr} 5$ reveal rotation of the La-Sm and inclination from the negative to flat. The richterites Gr 7-9 in the LAB show the highly inclined and enriched TRE patterns with high LILE, $\mathrm{Sr}, \mathrm{Rb}$ and troughs in $\mathrm{Nb}, \mathrm{Pb}$. The $\mathrm{Na}$ - rich have $\mathrm{Rb}, \mathrm{Ba}$, variable Th peaks and essentially lower REEE with the MREE depressions (created in harzburgites).. Clinopyroxenes show Th, $\mathrm{U}, \mathrm{Sr}$ peaks related to carbonatites.

The amphibole-ricjh mantle was farmed at the margin of the craton where subduction - related $\mathrm{Na}$ and $\mathrm{K}$ (silica-rich) fluids percolated through mantle with abundant eclogites causing amphibolization in several stages

Supported by RFBR grant 19-05-00788a
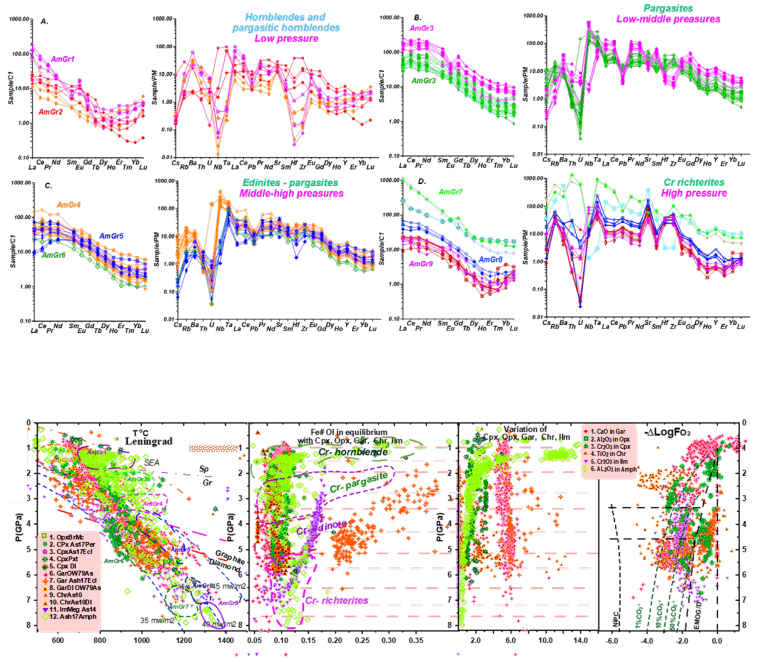